\title{
How do harpacticoid grazing rates differ over a tidal cycle? Field verification using chlorophyll-pigment analyses
}

\author{
Alan W. Decho* \\ Department of Zoology \& Physiology, Louisiana State University, Baton Rouge, Louisiana 70803, USA
}

\begin{abstract}
Four species of meiobenthic copepods were examined for diatom feeding. Microscopic analysis of gut-pellet contents from field-collected individuals indicated frequent ingestion of diatoms by 3 harpacticoids (Scottolana canadensis, Microarthridion Littorale, Cletocamptus deitersi) while occasional diatom ingestion occurred in Paronychocamptus huntsmani. Frustules were usually empty and broken, indicating that contents were digested. Laboratory experiments using ${ }^{14} \mathrm{C}$-labeling showed assimilation of diatoms by the 3 species examined. Field grazing rate studies were conducted over different portions of a tidal cycle using fluorescent chlorophyll-pigment analysis of gut-contents. Highest diatom consumption $(p<0.05)$ accurred just after the mudflat became exposed (i.e. Early Low Water level, ELW) for S. canadensis, while consumption at Late Low Water (LLW- i.e. after mudflat is exposed for several hours) was reduced. $M$. littorale showed a somewhat similar pattern in that highest consumption rates $(p<0.05)$ also occurred during ELW. However, during High Water $(\mathrm{HW})$ and LLW a similar (but reduced) feeding rate was measured. P. huntsmani appeared to only ingest diatoms (i.e. chlpigments) during HW. Relationships of feeding processes over a tidal cycle are discussed with regard to distributional patterns in intertidal and subtidal habitats.
\end{abstract}

\section{INTRODUCTION}

Diatoms are known from both laboratory and field studies to be an important food resource of many meiobenthic harpacticoids (Lee et al. 1976, Sellner 1976, Brown \& Sibert 1977, Harris 1977, Lee et al. 1977. Vanden Berghe \& Bergmans 1981, Ustach 1982, Admiraal et al. 1983, Montagna 1984, Carman \& Thistle 1985, Lee et al. 1985, Chandler 1986, Decho 1986, Decho \& Castenholz 1986, Nilsson 1987, Decho \& Fleeger 1988a, b). Laboratory studies (Decho 1986) have indicated that certain harpacticoids consume diatom food resources at different rates over portions of a simulated tidal cycle. Field verification of the observed feeding patterns represents an important step in understanding harpacticoid feeding processes.

Radiolabels are frequently used to measure feeding rates, and have been applied effectively in a wide variety of studies under field conditions. However, in order to examine feeding rates over a tidal cycle,

\footnotetext{
- Present address: CSIRO Marine Laboratory, PO Box 120, Cleveland, Queensland 4163, Australia
}

radiolabels could not be effectively used in these field studies due to associated hydrodynamic constraints. The dispersion of radiolabels must be contained; therefore, an enclosure (i.e. a capped core tube inserted into the sediment) is generally used. Any enclosure, however, reduces natural hydrodynamic perturbations and excludes routine macro-predatory disturbances (i.e. fish, crabs, shrimp, etc.) which may occur during highwater conditions (Eckman 1979). These natural perturbations and disturbances would be expected to affect feeding rates of a benthic assemblage.

Instead, the chlorophyll gut-fluorescence method of Mackas \& Bohrer (1976) with modifications by Dagg \& Wyman (1983) was employed for the present study. This technique measures the amount of chlorophyll and pheopigments (i.e. degradation products of chlorophyll) present in the alimentary canal of fieldcollected copepods by fluorescence. The method has been frequently used in water-column studies investigating calanoid copepod grazing on diatoms (e.g. Dagg 1983, Tande \& Bamstedt 1985, Stearns 1986, Wang \& Conover 1986, Dagg \& Walser 1987). By concurrently measuring gut-retention times under these 
same conditions (i.e. temperature, food concentration, tidal level) (sensu Dagg \& Walser 1987), grazing rates on diatoms can be estimated over different parts of a tidal cycle.

This study was designed to: (1) determine if diatoms are ingested and assimilated as a food resource by 3 species of harpacticoids; (2) determine if grazing rates on this food resource vary in the field over a tidal cycle; and (3) compare grazing rates with previous laboratory studies.

\section{METHODS}

Copepods used in laboratory and field experiments were collected from the lower regions of an intertidal mudflat near the Louisiana Marine Center (LUMCON) at Cocodrie, Louisiana, USA $\left(29.16^{\circ} \mathrm{N}, 90.41^{\circ} \mathrm{W}\right)$ near the sampling site of Phillips \& Fleeger (1985). To determine if diatoms were ingested and utilized as a food resource, several observational and experimental procedures were used.

Harpacticoid gut-content analysis. Harpacticoid gut-content analyses were conducted to determine the presence or absence of diatom. frustules in copepod guts, the presence of which would indicate recent ingestion of diatoms by harpacticoids. Gut contents, from field-collected individuals fast-frozen in liquid nitrogen, were dissected out of the gut and observed by light microscopy under oil immersion.

Laboratory feeding experiments. Three harpacticoid species: Scottolana canadensis (Wiley), Microarthridion littorale (Poppe), and Cletocamptus deitersi (Richard) were offered radiolabeled diatoms $\left({ }^{14} \mathrm{C}\right)$ in laboratory experiments. Cultures of the sediment diatom Amphora tenerrima (Aleem \& Hustedt), isolated from the harpacticoid habitat, were grown in Erdschreiber media and labeled in their log phase of growth with $0.33 \mu \mathrm{Ci} \mathrm{ml}^{-1}$ (final conc) $\mathrm{NaH}^{14} \mathrm{CO}_{3}$ (New England Nuclear, $10 \mu \mathrm{g} \mu \mathrm{Ci}^{-1}$ ) for $48 \mathrm{~h}$ in constant light. Unincorporated label was then removed by multiple centrifugations, and the culture was resuspended each time in sterile (15\% salinity) artificial seawater (ASW). Food concentrations (measured by triplicate subsamples) and specific activities of diatoms used in feeding experiments are listed in Table 1. Each experiment was run in triplicate. For each experiment, 150 adults of each species were prestarved for no longer than $30 \mathrm{~min}$, placed in sediment wells containing a known concentration of labeled diatoms with $1 \mathrm{~cm}$ water cover (ASW), and allowed to feed for $1 \mathrm{~h}$. At this time the copepods were removed and washed in filtered $(0.22 \mu \mathrm{m})$ ASW. Twenty-five copepods were immediately fixed in $10 \%$ formalin in ASW and placed in scintillation vials ( 6 individuals per vial) with $1.0 \mathrm{ml}$ $\mathrm{KOH}(10 \%)$ heated for $2 \mathrm{~h}\left(45^{\circ} \mathrm{C}\right)$ and counted on a Beckman LS8000 Liquid Scintillation Counter (LSC) using Universolv as the scintillation cocktail. Quenching was corrected for using the external standards ratio method. From the remaining copepods, 25 individuals were placed in 'Cold-Feed' sediment wells containing an unlabeled environment of sediment, ASW and diatoms. Copepods were allowed to feed for $3 \mathrm{~h}$ in order to clear their guts of any labeled-diatom material. Twenty-four individuals were placed in $25 \mathrm{ml}$ respiration flasks ( 6 individuals per flask) under similar conditions (i.e. food conc., etc.) as the cold-feed wells and allowed to feed for $2 \mathrm{~h}$. Respiration of ${ }^{14} \mathrm{CO}_{2}$ was measured according to the methods of Hobbie \& Crawford (1969).

To correct for uptake of ${ }^{14} \mathrm{C}$-label not due to the ingestion of labeled diatoms, controls, consisting of sediment wells containing the filtrate $(0.22 \mu \mathrm{m})$ of ${ }^{14} \mathrm{C}$ diatoms incubated for $1 \mathrm{~h}$ (approximate feeding incubation period) were used. This filtrate contained ${ }^{14} \mathrm{C}$ exudates of the diatoms and leaked intracellular contents, which the copepods were exposed to during the

Table 1. Results of laboratory feeding experiments on harpacticoid copepods using ${ }^{14} \mathrm{C}$-diatoms (Amphora tenerrima) as a food resource. Mean ( $\pm \mathrm{SE}$ ) food concentrations; activities are dpm (disintegrations per minute) and represent means ( \pm SE) corrected for controls

\begin{tabular}{|c|c|c|c|c|c|}
\hline Harpacticoid species & $\begin{array}{c}\text { Mean food } \\
\text { concentrations } \\
\text { (no. cells } \mathrm{cm}^{-2} \text { ) }\end{array}$ & $\begin{array}{c}\text { Specific } \\
\text { activity } \\
\left(\text { dpm cell }{ }^{-1}\right)\end{array}$ & $\begin{array}{c}{ }^{14} \mathrm{C} \text {-ingested } \\
(\mathrm{dpm})\end{array}$ & $\begin{array}{c}{ }^{14} \mathrm{C} \text { remaining } \\
\text { in copepods (after } \\
3 \mathrm{~h} \text { post-feeding) } \\
(\mathrm{dpm})\end{array}$ & $\begin{array}{c}\% \text { Label } \\
\text { respired } \\
\text { (during } 3 \mathrm{~h} \\
\text { post-feeding) }\end{array}$ \\
\hline Scottolana canadensis & $\begin{array}{c}775000 \\
( \pm 16300)\end{array}$ & $3.1-4.3$ & $186 \pm 16$ & $99 \pm 12$ & $25 \pm 14$ \\
\hline Microarthridion littorale & $\begin{array}{c}510760 \\
( \pm 14875)\end{array}$ & $1.8-2.6$ & $74 \pm 12$ & $37 \pm 9$ & $38 \pm 18$ \\
\hline Cletocamptus deitersi & $\begin{array}{c}611400 \\
( \pm 21634)\end{array}$ & $2.6-3.5$ & $106 \pm 18$ & $63 \pm 15$ & $32 \pm 13$ \\
\hline
\end{tabular}


$1 \mathrm{~h}$ feeding experiments. Eighteen copepods were placed in these control wells and incubated for $1 \mathrm{~h}$, at which time they were removed, washed and prepared for LSC ( 6 individuals per scintillation vial)

Field grazing rate experiments. Field experiments were conducted during late March to measure consumption rates of diatoms and microalgae by harpacticoid species over 3 different portions of a tidal cycle: (1) High Water (HW), when the mudflat was covered by water; (2) Early Low Water (ELW), just after the mudflat was exposed; and (3) Late Low Water (LLW), after the mudflat had been exposed for several hours. Consumption rates of diatoms were estimated by the gut fluorescence method of Dagg \& Wyman (1983) with slight modifications (see below) for sediment. All experiments were conducted at the lower portion of an intertidal mudflat. Harpacticoids were extracted by collecting sediment, quickly sieving it through $125 \mu \mathrm{m}$ mesh and immediately freezing the retained fraction in liquid nitrogen (in darkness). Samples were kept frozen in dry ice (in darkness) while transported back to the laboratory, and remained frozen for a maximum of $4 \mathrm{~h}$.

In the laboratory, the animals were extracted, washed and separated according to species using minimal light exposure, to prevent degradation of pigments within copepod guts. Only adults were used in subsequent analyses. Twenty individuals of each species (Scottolana canadensis, Microarthridion littorale, and Paronychocamptus huntsmanl) were placed on replicate separate glass-fiber filters (Whatman GF/F). For $S$. canadensis, only adult females were nsed because of the great sexual dimorphism in size (Coull 1972). The samples (and filters) were homogenized in $15 \mathrm{ml}$ of $90 \%$ acetone, and the fluorescence of the filtrate determined before and after acidification in $10 \% \mathrm{HCl}$ using a Turner Designs Model 10 Fluorometer calibrated for chlorophyll a. Chlorophyll a and pheopigment content of each copepod was calculated using equations modified from Strickland \& Parsons (1968) by Dagg \& Wyman (1983). Gut-pigment was determined by summation of gut-chlorophyll and gut-pheopigment, and expressed as ing chl-equivalent pigment per individual'. All data were corrected for the small amount of analytical interference from copepod tissues (control fluorescence). Controls represented copepods previously starved for $12 \mathrm{~h}$ in filtered SW. These copepods were observed microscopically before analysis to confirm the absence of gut-pellets. For each species, 6 replicate samples were used for treatments (HW, ELW, and LLW), and controls (20 individuals per replicate). Grazing rates were calculated from these gut-pigment estimates.

Ambient concentrations of sediment chlorophyll a were determined from 3 replicate $1 \mathrm{~cm}^{3}$ sediment core samples, corrected for sediment dry weight. These con- centrations are primarily due to diatoms, which were abundant on the mudflat at the time of the experiment. Slight overestimations in chlorophyll $a$, due to small amounts of chlorophyll b (Daemen 1986), were assumed to be negligible since cyanobacteria (a major source of chl b) were not present in detectable abundances at the time of sampling. Concentrations of chlorophyll $a$ in the overlying water during HW conditions were also measured.

Separate gut-retention times were measured 'in situ' for each harpacticoid species at each portion of the tidal cycle. To estimate gut passage times, core tubes (3.5 cm diameter) were placed in sediments and $500 \mu \mathrm{l}$ azo-carmine (Sigma Chem. Co.) in ASW solution (1\% w/v) was added to each as an inert tracer. Core tubes were removed from the sediment and immediately frozen at 10 min intervals, starting at 40 , ending at 100 min. Later, the posterior gut of each species was examined for the location of azo-carmine with time to approximate gut-passage times for each tidal condition. Gut-passage times were used in conjunction with gut-pigment contents to estimate grazing rates (ng pigment copepod ${ }^{-1} \mathrm{~h}^{-1}$ ) after Dagg \& Wyman (1983).

In order to standardize ingestion rates for the relative size differences between the 3 species of harpacticoids. adults $(n=75)$ of each species were dried and weighed on a Mettler AE163 analytical balance. Five replicate samples were always used. These weights were necessary to calculate consumption rates (g copepod tissue) $^{-1}$ (i.e. weight-specific grazing rates).

Results of guit-passagje times dnci ingestion rates were analyzed by General Linear Models ANOVA (SAS Institute 1986), Log $(x+1)$ transformed data were used for analysis of gut passage times and arcsintransformed data were used for analyses of ingestion rates. If a significant $(p<0.05)$ difference was indicated, Bonferroni's test was used for a posteriori comparison of means (SAS Institute 1986).

\section{RESULTS}

\section{Gut content analyses}

Analyses of gut-contents from field-collected individuals indicate that diatoms, sediment particles, and some bacterium-sized particles were ingested by 3 species of harpacticoids (Scottolana canadensis, Microarthridion littorale, and Cletocamptus deitersi). Diatom frustules comprised ca 30 to $70 \%$ of the gutpellet (by volume). A fourth species (Paronychocamptus huntsmani) contained only occasional frustules, with the majority of the gut-pellet contents composed of sediment particles (with some bacterium-sized particles) and unidentified amorphous material. 


\section{Laboratory feeding experiments}

Food concentrations and specific activities of diatoms used in feeding experiments are given in Table 1. Feeding experiments indicate significant uptake of ${ }^{14} \mathrm{C}$-labeled diatoms after $1 \mathrm{~h}$ feeding by all 3 species of harpacticoids (Table 1). After $3 \mathrm{~h}$ of cold-feeding (on unlabeled diatoms), to clear the guts of labeled material, a significant portion of the ingested ${ }^{14} \mathrm{C}$-label still remained in all 3 species of harpacticoids indicating assimilation of ${ }^{14} \mathrm{C}$-diatoms. A large portion (25 to $38 \%$ ) of the ingested label, lost during cold-feeding, was accounted for through respiratory losses of ${ }^{14} \mathrm{CO}_{2}$, a fact which further indicates assimilation of diatoms by harpacticoids.

\section{Field grazing experiments}

Field-sampling occurred during the movement of a weather front into the local area. Temperatures during sampling remained relatively constant, ranging from 12 to $14^{\circ} \mathrm{C}$, with strong north winds (20 to 25 knots) prevailing. Sediment chlorophyll $a$ and pheopigment values were highest at ELW (Early Low Water conditions) (Table 2).

Table 2. Ambient sediment and water-column chlorophyllpigment concentrations during field grazing experiments using harpacticoid copepods. HW: high water level (i.e. high tide); ELW: early low water level (i.e. just after mudflat becomes exposed); LLW: late low water level (i.e. several hours after mudflat becomes exposed). Sediment concentrations are corrected for sediment dry weight

\begin{tabular}{|lrrr|}
\hline Sample & Tide & $\begin{array}{c}\text { Chlorophyll a } \\
\text { (ng pigment } \mathrm{cm}^{-3} \\
\text { sediment) }\end{array}$ & $\begin{array}{c}\text { Pheopigment } \\
\text { (ng pigment } \\
\mathrm{cm}^{-3} \text { sediment) }\end{array}$ \\
\hline Sediment & HW & $1705 \pm 633$ & $11630 \pm 1977$ \\
& ELW & $2466 \pm 591$ & $18980 \pm 5320$ \\
WLW & $2245 \pm 786$ & $15864 \pm 3015$ \\
Water column & HW & $954 \pm 327$ & $1740 \pm 1460$ \\
- Concentrations expressed as ng pigment $\mathrm{ml}^{-1}$ seawater
\end{tabular}

Control harpacticoids, prestarved for $12 \mathrm{~h}$, contained $0.0117 \pm 0.0041 \mathrm{ng} \mathrm{chl} \mathrm{ind.}{ }^{-1}$ and $0.1367 \pm 0.0137 \mathrm{ng}$ pheopigment ind. ${ }^{-1}$ for Scottolana canadensis, 0.0083 $\pm 0.0041 \mathrm{ng}$ chl ind ${ }^{-1}$ and $0.1100 \pm 0.0044 \mathrm{ng}$ pheo ind. $^{-1}$ for Microarthridion littorale, and $0.0077 \pm$ $0.0041 \mathrm{ng}$ chl ind. ${ }^{-1}$ and $0.1203 \pm 0.0140 \mathrm{ng}$ pheo ind. $^{-1}$ for Paronychocamptus huntsmani.

Scottolana canadensis showed the highest gut-pigment content during ELW conditions $(0.69 \pm 0.13 \mathrm{ng}$ pigment ind. $\left.{ }^{-1}\right)$, with significantly $(p<0.05)$ lower val- ues during $\mathrm{HW}\left(0.51 \pm 0.06 \mathrm{ng}\right.$ pigment ind $\left.{ }^{-1}\right)$ and LLW conditions $\left(0.21 \pm 0.05 \mathrm{ng}\right.$ pigment ind. $\left.{ }^{-1}\right)$, respectively. Also, gut-passage times were similar during $\mathrm{HW}$ and ELW conditions, 62 to $65 \mathrm{~min}(p>0.05)$, but significantly $(p<0.05)$ longer, $80 \mathrm{~min}$, during LLW (Fig. 1). The resulting grazing rates, calculated from

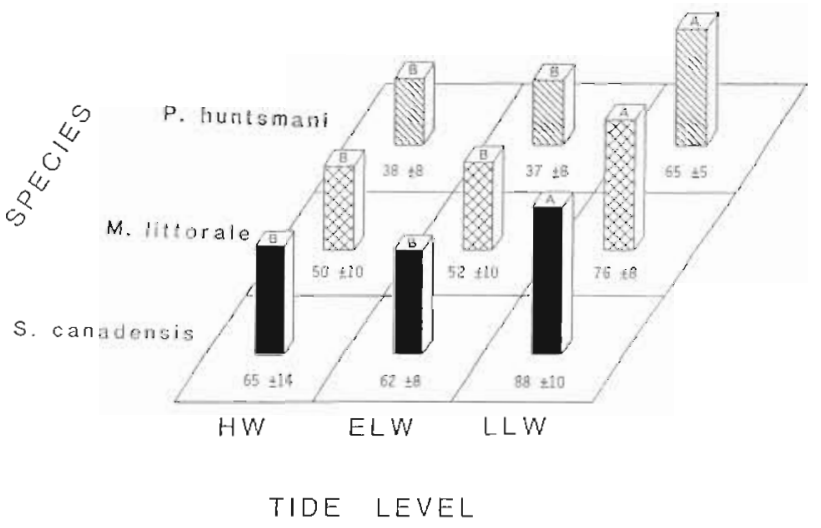

Fig. 1 Mean ( \pm SE) gut-retention times for 3 species of harpacticoid copepod over different portions of a tidal cycle Values given in minutes. HW: high water level; ELW: early low water level; LLW: late low water level. Letters on bars are results of Bonferroni tests; the same letter across a given row (species) indicates the means are not significantly different

gut-pigment contents and gut-passage data, show highest consumption during ELW, 0.67 ng chl-equiv. pigment ind. ${ }^{-1} \mathrm{~h}^{-1}$ with significantly lower rates $(p<0.05)$ during HW $(0.47)$ and LLW $(0.14)$, respectively (Fig. 2)

Microarthridion littorale showed highest gut-pigment contents during ELW $\left(0.42 \pm 0.13 \mathrm{ng}\right.$ pigment ind. $\left.{ }^{-1}\right)$, with slightly lower values during HW and LLW condi-

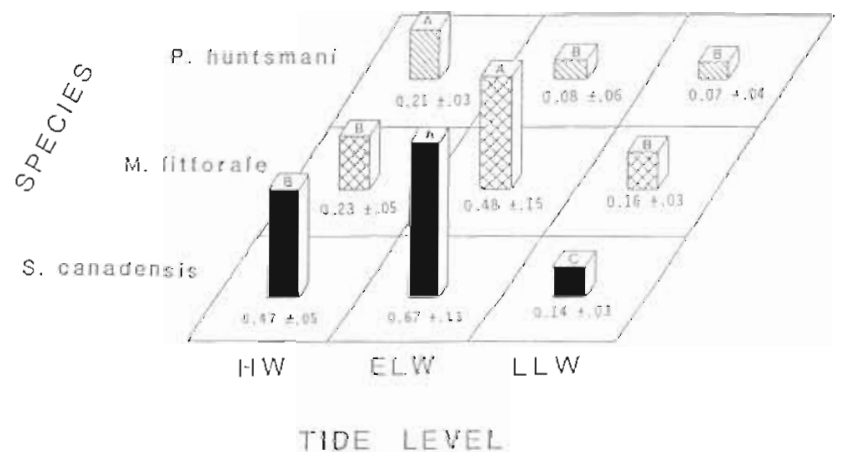

Fig. 2. Mean ( $\pm \mathrm{SE}$ ) ingestion rates of chlorophyll-equivalent pigment by 3 species of harpacticoid copepod over different portions of a tidal cycle. Values are ng chl-equiv, pigment ind. $^{-1} \mathrm{~h}^{-1}$ HW high water level; ELW early low water level. LLW: late low water level. Letters on bars are results of Bonferroni tests; the same letter across a given row (species) indicates the means are not significantly different 
tions, ranging from 0.18 to $0.20 \mathrm{ng}$ pigment ind. ${ }^{-1}$. Gutpassage times were similar at HW and ELW (50 and 52 min, respectively), but significantly longer $(p<0.05)$ during LLW (76 min; Fig. 1). Consumption rates of diatoms were greatest at ELW and significantly less $(p<0.05)$ at HW and LLW (Fig 2). Paronychocamptus huntsmani showed gut-pigment contents which did not differ from controls ( $p>0.05$ ) except during HW when $0.13 \pm 0.02 \mathrm{ng}$ pigment ind. ${ }^{-1}$ was present.

Mean tissue dry-weights (and lengths) used to standardize ingestion rates for species size differences are listed in Table 3. Resulting weight-specific ingestion rates (to remove the effect of relative size differences between the 3 harpacticoid species) indicate that all 3 harpacticoids consume diatoms at similar rates (per g tissue) during HW (Table 3). Highest consumption for Scottolana canadensis and Microarthridion littorale occurred during ELW. Significant consumption for Paronychocamptus huntsmani occurred only during HW.

\section{DISCUSSION}

In laboratory studies, the presence of water-cover conditions (comparable to High Water [HW] and Late Low Water (LLW) in the present study, but with no hydrodynamic or disturbance effects) dramatically affected the feeding rates and mode of feeding (benthic vs planktonic) of certain harpacticoid species (Decho 1986). The present field study confirms that ingestion rates of diatoms by these same harpacticoid species vary over a tidal cycle (as measured by gut-pigment contents). These observed differences are speciesspecific and relate to the differing feeding modes used by each harpacticoid. Scottolana canadensis showed highest rates of feeding during Early Low Water (ELW) conditions, just after the tide had receded and the mudflat was still very wet. Feeding rate was significantly lower during HW conditions (i.e. high-tide) and lower still at LLW (after the mudflat had been exposed for several hours). This behavior is consistent with information indicating a diet of planktonic diatoms (Chandler 1986, Lonsdale \& Levinton 1986), and a pattern of feeding on suspended cells in the immediate overlying water column (Decho 1986) from burrows which it constructs (Chandler \& Fleeger 1988). Approximately similar (though slightly lower) feeding rates were found for Microarthridion littorale at $\mathrm{HW}$ and LLW conditions, Laboratory studies show that $M$. littorale compensates for these changing water-level conditions by changing its mode of feeding (Decho 1986). Feeding during HW occurs primarily while swimming and consists mainly of planktonically-suspended food resources. Feeding during LW (i.e. LLW in the present study) is benthic while crawling over and through the sediment. Paronychocamptus huntsmani is mainly found in subtidal (and occasionally lower intertidal) regions of Louisiana marshes (Fleeger 1985). This species appears to require water-cover for ingestion of food since significant consumption occurred in the intertidal region only during $\mathrm{HW}$.

Interestingly, highest gut contents and feeding rates occur during ELW for both Scottolana canadensis and Microarthridion littorale. The immediate causes are unknown but may relate to several factors. First, there is an abundant water film covering the mudflat at ELW. The surface sediment is flocculent which could facilitate the movement of meiobenthic copepods, allowing them to readily find and ingest food-rich patches. Second, there is an absence, at ELW, of the disturbing wave actions or hydrodynamic influences typically present during HW (Eckman 1983, Palmer \& Gust 1985, Palmer 1986). Small fish predators (Feller \& Kacynski 1975, Bell \& Coull 1978, Bell 1980, Fitzhugh \& Fleeger 1985. Smith \& Coull 1987) also can potentially affect feeding behaviors. $S$. canadensis, for example, in laboratory microcosms moves very quickly to the lower portion of its burrow (ca 1 to $1.5 \mathrm{~cm}$ vertical depth) in response to a predator-like physical disturbance at the surface (pers. obs.). Thirdly, the availability and accessability of potential food (i.e. diatoms and flocculent aggregate material) may be greatest at the sediment surface at this time.

Table 3. Standardized weight-specific ingestion rates of chlorophyll-equivalent pigments by harpacticoid copepod species. HW: high water level; ELW: early low water level, LLW late low water level. Significance levels: ns, not significantly different from zero $(p>0.05)_{i}{ }^{*}$ significant $(p<0.05) ; \cdots$ significant $(p<0.01)$

\begin{tabular}{|c|c|c|c|c|c|}
\hline \multirow[t]{2}{*}{ Harpacticoid species } & \multirow[t]{2}{*}{$\begin{array}{l}\text { Length } \\
(\mathrm{mm})\end{array}$} & \multirow{2}{*}{$\begin{array}{c}\text { Mean }( \pm S E) \\
\text { dry weight } \\
(\mu g)\end{array}$} & \multicolumn{3}{|c|}{$\begin{array}{c}\text { Ingestion rate } \\
\text { (ng chl-equiv. pigment ( } \mu \text { g dry tissue) }{ }^{-1} \mathrm{~h}^{-1} \text { ) }\end{array}$} \\
\hline & & & HW & ELW & LLW \\
\hline Scottolana canadensis & $1.10-1.20$ & $5.50 \pm 0.60$ & $0.09 \pm 0.01^{\circ}$ & $0.12 \pm 0.02^{\circ}$ & $0.03 \pm 0.02^{n s}$ \\
\hline Microarthridion littorale & $0.50-0.72$ & $2.64 \pm 0.18$ & $0.09 \pm 0.02$ & $0.18 \pm 0.05 \cdots$ & $0.06 \pm 0.002^{\circ}$ \\
\hline Paronychocamptus huntsmani & $0.40-0.60$ & $2.38 \pm 0.12$ & $0.09 \pm 0.01^{\circ}$ & $0.03 \pm 0.03^{\mathrm{ns}}$ & $0.03 \pm 0.02^{\mathrm{ns}}$ \\
\hline
\end{tabular}


Food availability on the surface of a mudflat is likely to fluctuate considerably over a tidal cycle. More than a $50 \%$ fluctuation in particulate organic carbon and chlorophyll a can occur in near-bottom water-layers during a tidal cycle (Roman \& Tenore 1978). During high water much of the sediment-floc, benthic diatoms, detritus, and phytoplankton (which had previously settled to the bottom mud) is resuspended into the water column. It settles out before the tide flat is exposed, causing higher concentrations on the surface at low tide. Similar patterns occurred in the present study. Sediment chlorophyll and pheopigment concentrations were highest during low water (Table 2). Also, the nutritive value of the settled organic material may be enhanced via the previous resuspension and mixing (sensu Tenore 1976). This enhancement may provide a 'new' composition of food for mudflat meiofauna with each tidal ebb. This 'new' food is first available in high sediment concentrations during ELW (Jenness \& Duineveld 1985). Therefore, the high ambient food supply, flocculent nature of the sediment, and lack of various disturbances (normally imposed by watercover) may combine to make ELW an ideal feecing time for some mudflat meiobenthos.

Gut-retention times also varied with tidal conditions. Longest retention times occurred consistently at LLW. It is, however, important to note that the use of a relatively inert tracer (such as azo-carmine) and its first appearance in the feces, will provide a minimum estimate of gut-retention time. Observations suggest that significant mixing occurs in the anterior and middle portions of copepod guts during passage (pers. obs.). Since the gut contents do not form a distinct intact pellet until they reach the posterior portion of the gut, retention times were determined by observing the movement of the tracer only in the posterior portion of the gut. Relative changes in gut-retention times are a function of temperature (Kiorboe et al. 1982, Dagg \& Wyman 1983), which remained relatively constant throughout the present field study, and feeding rate (Richman 1966, Geller 1975, Arashkevich 1977. Baars \& Oosterhuis 1984, Simard et al. 1985). Scottolana canadensis predictably showed longest gut-retention times during LLW when feeding rates were lowest, and much shorter retention times during HW and ELW when feeding rates were much higher. Microarthridion littorale followed a similar pattern, having longest retention times during LLW (however feeding rates were only slightly lower than feeding rates at HW). Differences in the type of food ingested (benthic vs planktonic) may have affected the relative retention at these 2 times.

Size differences of copepod species also affect grazing rates. Aduits of Scottolana canadensis are typically twice as large as, and ingest proportionately more than, adults of either Microarthridion littorale or Paronychocamptus huntsmani. However, weight-specific consumption rates (removing the effect of relative size differences among species) are similar for all 3 species during HW. Also, both $S$. canadensis and $M$. littorale feed at similar rates during ELW (on a per weight basis).

The use of fluorescent gut-pigments as an index of herbivorous grazing is a conservative feeding estimate for 2 reasons. First, much of the benthic and nearbottom food material (containing pigment) represents sinking senescent phytoplankton, benthic diatoms, and detritus. A portion of the chlorophyll-derived pigments within this flora will be in various stages of decay, some of which are non-fluorescent forms (Tietjen 1968). Ingestion of these pigments will not be detected during subsequent gut-pigment analyses, and therefore will underestimate ingestion rates. Second, a portion of the ingested chlorophyll (which is detectable) is converted by the digestive process to non-fluorescent forms. Conversion to non-fluorescent forms ranges from about $11 \%$ (Dagg \& Walser 1987) to over $34 \%$ (Shuman \& Lorenzen 1975) of the ingested chlorophyll in planktonic copepods. A conversion factor, to compensate for these losses, was not applied to my data because the magnitude of these losses are not known for benthic harpacticoids. The exact mechanjsm for this conversion is not known (Downs \& Lorenzen 1986) but can represent a possible source of error in measuring feeding rates. Also, if the utilization of food resources changes (benthic vs planktonic) over a tidal cycle, the pigment concentrations of ingested food items may concomitantly change (for example benthic cells might have more pigment per cell than planktonic cells). If this occurred, actual feeding (i.e. number of cells ingested) over a tidal cycle could conceivably remain constant while feeding rates, determined by ingested pigment, would appear to change over the same period.

Intertidal harpacticoid biology is apparently dependent on the stage of the tide and tidal currents. Sediment densities and patchiness are highest at low-tide (Palmer \& Brandt 1981, Fleeger et al. 1984, Decho \& Fleeger 1988b) and feeding strategies change (Decho 1986). Several of these activities could relate to the distribution of sediment or water column diatoms. During low water, patchiness is most pronounced in Microarthridion littorale which actively forages and feeds at this time. This patchiness appears to result from aggregating around microbial (food) clumps (Decho \& Fleeger 1988b). In Scottolana canadensis, which does not actively move or feed at low-water, patchiness is not related to distribution of food clumps. During high water, some species utilize planktonic food resources by leaving the sediment (i.e. M. Littorale, Cletocamptus deitersi; also S. canadensis to some extent) and swim- 
ming in the water column. Other species (i.e. $S$. canadensis) construct burrows and filter suspended material above the burrow. Resuspension during times of water-cover (whether active or passive) appears to be a common event for many harpacticoids in intertidal muddy habitats (Palmer \& Brandt 1981. Fleeger et al. 1984). It is not yet known if entry into the water column is good or bad for the harpacticoids (i.e. predation in the water column may be great). More empirical data on individual species are needed to fully evaluate how these resuspensions relate to feeding processes and survival. However, if many harpacticoids feed while in the water column on suspended benthic or water column resources, it might suggest that harpacticoids have evolved behaviors necessary to track phytal food resources over tidal cycles.

Many meiofauna show distributions related to tidal variation and amplitude (see Hicks \& Coull 1983 for review). Intertidal transition zones (i.e. mudflats) can, owing to their tidal influences, have a most pronounced effect on distributions via (1) extremes in physical conditions, (2) water-cover effects on feeding rates, and (3) hydrodynamic and biotic disturbances. In Louisiana marshes, these effects can be exaggerated. Tides are often wind-dominated, which can result in prolonged (i.e. several days to weeks) low or high tides. It is therefore not surprising that abundances of certain mudflat harpacticoids in Louisiana marshes follow these tidal anomalies on a seasonal scale (Phillips \& Fleeger 1985). The observed differences in feeding rates over different portions of a tidal cycle provide further evidence that intertidal meiobenthos do not feed at constant rates, and may even be limited distributionally to some extent by their ability to feed, over a tidal cycle. Also, food resource utilization (i.e. benthic vs planktonic) may change with changing tidal level. The frequent resuspension, mixing and settling of both meiobenthic animals and their food resources are imposed by the changing tidal levels. This resuspension implies that small-scale distributional patterns of some meiobenthic species and their food resources must develop relatively quickly, and are probably short-lived (i.e. less than the length of a tidal cycle).

Acknowledgements. I thank Dr M. J. Dagg, Louisiana Universities Marine Consortium (LUMCON), for technical assistance, consultation, and the use of his laboratory for chlorophyll-pigment analyses; the staff of LUMCON for use of their Marine Center, equipment, and their helpful assistance during various portions of field experimentation; Dr J. W Fleeger for suggestions and helpful review on earlier versions of this manuscript; Dr M. Sullivan, Mississippi State University, for identification of benthic diatoms used in feeding experiments; and the suggestions of anonymous reviewers. This work was funded by NSF Grant OCE-8313109 and Sigma Xi Grant-in-Aid to A. W Decho.

\section{LITERATURE CITED}

Admiraal, W., Bouwman, L. A., Hoekstra, L., Romeyn, K (1983). Qualitative and quantitative interactions between microphytobenthos and herbivorous meiofauna on a brackish intertidal mudflat. Int. Revue ges. Hydrobiol. 68 : 175-191

Arashkevich, E. G. (1977). Duration of food digestion in marine copepods. Polskie Arch. Hydrobiol. 24 (Suppl.): $431-438$

Baars, M. A., Oosterhuis, S. S. (1984). Diurnal feeding rhythms in North Sea copepods measured by gut fluorescence, digestive enzyme activity, and grazing on labelled food. Neth. J. Sea Res. 18: 97-119

Bell, S. S. (1980). Meiofauna-macrofauna interactions in a high salt marsh habitat. Ecology 50:487-505

Bell, S. S., Coull, B. C. (1978). Field evidence that shrimp predation regulates meiofauna. Oecologia (Berl.) 35: 141-148

Brown, T. J., Sibert, J. R. (1977). Food of some benthic harpacticoid copepods. J. Fish. Res. Bd Can. 35: 1028-1031

Carman, K. R., Thistle, D. (1985). Microbial food partitioning by three species of benthic copepods. Mar. Biol. 88: 143-148

Chandler, G. T (1986). High density culture of meiobenthic harpacticoid copepods within a muddy sediment substrate. Can. J. Fish. aquat. Sci. 43: 53-59

Chandler, G. T., Fleeger, J. W. (1988). Facilitative and inhibitory interactions among estuarine meiobenthic harpacticoid copepods. Ecology (in press)

Coull, B. C. (1972). Scottolana canadensis (Willey) (Copepoda, Harpacticoida) redescribed from the United States east coast. Crustaceana 22: 210-214

Daemen, E. A. M. J. (1986). Comparison of methods for the determination of chlorophyll in estuarine sediments. Neth. J. Sea Res. 20: 21-28

Dagg, M. J. (1983). A method for the determination of copepod teeding rates during short time intervals. Mar. Biol. 75 : $63-67$

Dagg, M. J., Wyman, K. D. (1983). Natural ingestion rates of the copepods Neocalanus plumchrus and $N$. cristatus calculated from gut contents. Mar. Ecol. Prog. Ser. 13: $37-46$

Dagg, M. J., Walser, W E. (1987). Ingestion, gut passage, and egestion by the copepod Neocalanus plumchrus in the laboratory and in the subarctic Pacific Ocean. Limnol. Oceanogr. 32: 178-188

Decho, A. W. (1986). Water-cover influences on diatom ingestion rate by meiobenthic copepods. Mar. Ecol. Prog. Ser. 33: $139-146$

Decho, A. W., Castenholz, R. W (1986). Spatial patterns and feeding of meiobenthic harpacticoid copepods in relation to resident microbial flora. Hydrobiologia 131: 87-96

Decho, A. W., Fleeger, J. W. (1988a). Ontogenetic feeding shifts in the meiobenthic harpacticoid copepod Nitocra lacustris. Mar Biol. 97: 191-197

Decho, A W., Fleeger, J. W. (1988b). Microspatial dispersion of meiobenthic harpacticoids in response to food resource patchiness. J. exp. mar Biol. Ecol, (in press)

Downs, J. N., Lorenzen, C. J. (1986). The specific absorption coefficients of chlorophyllide a and pheophorbide a in $90 \%$ acetone, and comments on the fluorometric determination of chlorophyll and pheopigments. Limnol. Oceanogr. 31: 449-452

Eckman, J. E. (1979). Small-scale patterns and processes in a soft-substratum, intertidal community. J. mar. Res. 37 : $437-457$ 
Eckman, J. E. (1983). Hydrodynamic processes affecting benthic recruitment. Limnol. Oceanogr. 28: 241-257

Feller, R. J., Kaczynski, V W. (1975). Size selective predation by juvenile chum salmon (Oncorhynchus keta) on epibenthic prey in Pugget Sound. J. Fish. Res. Bd Can. 32: $1419-1429$

Fitzhugh, G. R., Fleeger, J. W. (1985). Goby (Pisces: Gobiidae) interactions with meiofauna and small macrofauna. Bull. mar. Sci. 36: 436-444

Fleeger, J. W (1985). Meiofaunal densities and copepod species composition in a Louisiana, U.S.A. estuary. Trans. Am. microsc. Soc. 104: 321-332

Fleeger, J. W., Chandler, G. T., Fitzhugh, G. R., Phillips, F. E. (1984). Effects of tidal currents on meiofauna densities in vegetated salt marsh sediments. Mar. Ecol. Prog. Ser 19 : $49-53$

Geller, W (1975). Die Nahrungsaufnahme von Daphnia pulex in Abhängigkeit von der Futterkonzentration, der Temperatur, der Körpergröße und dem Hungerzustand der Tiere. Arch. Hydrobiol. 48 (Suppl.): 47-107

Harris, R. P. (1977). Some aspects of the biology of the harpacticoid copepod Scottolana canadensis (Willey) maintained in laboratory cuiture. Chesapeake Sci. 18: 245-252

Hicks, G. R. F., Coull, B. C. (1983). The ecology of marine meiobenthic harpacticoid copepods. Oceanogr. mar. Biol. A. Rev. 21: 67-175

Hobbie, J. E., Crawford, C. C. (1969). Respiration corrections for bacterial uptake of dissolved organic compounds in natural waters. Limnol. Oceanogr. 14: 528-532

Jenness, M. I., Duineveld, G. C. A. (1985). Effect of tidal currents on chlorophyll a content of sandy sediments in the southern North Sea. Mar Ecol. Prog. Ser 21.283-287

Kiørboe, T., Mohlenberg, F., Nicolajsen, H. (1982). Ingestion rate and gut clearance in the planktonic copepod Centropages hamatus (Lilljeborg) in relation to food concentration and temperature. Ophelia 21: 181-194

Lee, J. J., Tietjen, J. H., Garrison, J. R. (1976). Seasonal switching in the nutritional requirements of Nitocra typica, a harpacticoid copepod from salt marsh aufwuchs communities. Trans. Am. microsc. Soc. 95: 628-637

Lee, J. J., Tietjen, J. H., Mastropaolo, G., Rubin, H. (1977). Food quality and the heterogeneous spatial distribution of meiofauna. Helgoländer wiss. Meeresunters. 30: 272-282

Lee, W Y., Zhang, X. K., Baalen, C. V., Arnold, C. R. (1985]. Feeding and reproductive performance of the harpacticoid Tisbe carolinensis (Copepoda, Crustacea) in four algal cultures. Mar Ecol. Prog. Ser. 24: 273-279

Lonsdale, D. J., Levinton, J. S. (1986). Growth rate and reproductive differences in a widespread estuarine harpacticoid copepod (Scottolana canadensis). Mar Biol 91: 231-237

Mackas, D., Bohrer, R. (1976). Fluorescence analysis of zooplankton gut contents and an investigation of diel feeding patterns. J. exp. mar. Biol. Ecol. 25: 77-85

Montagna, P. A. (1984). In situ measurements of meiobenthic grazing rates on sediment bacteria and edaphic diatoms. Mar Ecol. Prog. Ser. 18: 119-130

Nilsson, P. (1987). Demography of Mesochra lilljeborgi and Amonardia normani (Copepoda Harpacticoida) reared on two diatom diets. Mar. Ecol. Prog. Ser. 39: 267-274
Palmer, M. A. (1986). Hydrodynamics and structure: interactive effects on meiofauna dispersal. J. exp. mar Biol. Ecol. 104: 53-68

Palmer, M. A., Brandt, R. R. (1981). Tidal variation in sediment densities of marine benthic copepods. Mar. Ecol. Prog. Ser. 4: $207-212$

Palmer, M. A., Gust, G. (1985). Dispersal of meiofauna in a turbulent tidal creek. J mar. Res. 43: 179-210

Phillips, F. E., Fleeger, J. W. (1985). Meiofauna meso-scale variability in two estuarine habitats. Estuar. coast. Shelf Sci. $21745-756$

Richman, S. (1966). The effect of phytoplankton concentration on the feeding rate of Diaptomus oregonensis. Verh. int. Verein. Limnol. 16: 392-398

Roman, M. R., Tenore, K. R. (1978). Tidal resuspension in Buzzards Bay, Mass. I. Seasonal changes in the resuspension of organic carbon and chlorophyll a. Estuar. coast. mar. Sci. 6: $37-46$

SAS Institute, Inc (1986). SAS user's guide: statistics. SAS Institute, Inc. Cary, North Carolina

Sellner, B. W (1976). Survival and metabolism of the harpacticoid copepod, Thompsonula hyaenae (Thompson) fed on different diatoms. Hydrobiologia 50: 233-238

Shuman, F. R., Lorenzen, C. (1975). Quantitative degradation of chlorophyll by a marine herbivore. Limnol. Oceanogr. 20: $580-586$

Simard, Y., Lacroix, G., Legendre, L. (1985). In situ twilight grazing rhythms during diel vertical migrations of a scattering layer of Calanus finmarchicus. Limnol. Oceanogr. 30: 598-606

Smith, L. D., Coull, B. C. (1987). Juvenile spot (Pisces) and grass shrimp predation on meiobenthos in muddy and sandy substrates. J. exp. mar. Biol. Ecol. 105: 123-136

Stearns, D. E. (1986). Copepod grazing behavior in simulated natural light and its relation to nocturnal feeding. Mar. Ecol. Prog. Ser. 30: 65-76

Strickland, J. D. H., Parsons, T R. (1968). A practical handbook of seawater analysis. Bull. Fish. Res. Bd Can. 167: $1-310$

Tande, K. S., Bamstedt, U. (1985). Grazing rates of the copepods Calanus glacialis and C. finmarchicus in arctic waters of the Barents Sea. Mar. Biol. 87. 251-258

Tenore, K. R. (1976). Food chain pathways in benthic communities: a review with new observations on sediment resuspension and detrital recycling. In: Coull, B. C. (ed.) Ecology of marine benthos. Univ. South Carolina Press, Columbia

Tietjen, J. H. (1968). Chlorophyll and pheopigments in estuarine sediments. Limnol. Oceanogr. 13: 189-192

Ustach, J. F. (1982). Algae, bacteria, and detritus as food for the harpacticoid copepod, Heteropsyllus pseudonunni Coull \& Palmer. J. exp. mar. Biol. Ecol. 64: 203-214

Vanden Berghe, W. Bergmans, M. (1981). Differential food preferences in three co-occurring species of Tisbe (Copepoda, Harpacticoida). Mar Ecol. Prog. Ser. 4: 213-219

Wang. R., Conover, R. J. (1986). Dynamics of gut pigment in the copepod Temora longicornis and the determination of in situ grazing rates. Limnol. Oceanogr. 31 867-877 